\title{
Investigation on Mechanical Properties of Lightweight Concrete Partially Replacing Sawdust to Fine Aggregate
}

\author{
Shaik Nurulla ${ }^{*}$, Shaik Mustafa ${ }^{2}$, Yeddula Bharath Simha Reddy ${ }^{3}$ \\ ${ }^{1}$ Department of civil engineering, Nalanda Institute of engineering and technology, Sattenapalli, Guntur 522438, India \\ ${ }^{2}$ Department of civil engineering, Tirumala Engineering College, Narasaraopet, Guntur 522601, India \\ ${ }^{3}$ Vellore Institute of technology, Chennai 600127, India
}

Corresponding Author Email: nurushaik9676@yahoo.com

https://doi.org/10.18280/acsm.430210

Received: 15 January 2019

Accepted: 26 March 2019

\section{Keywords:}

environment, mechanical properties, sawdust, lightweight concrete, eco-friendly

\begin{abstract}
The major element that helps in damaging the environment is $\mathrm{CO}_{2}$, where it leads to disturb the human race as well as the entire bio-diversity of the environment. As increasing demand for the construction of buildings, Dams and many other projects which directly helps in increase in demand of cement production. As of the records 2001 a total of $7 \%$ of pollution in the entire environment is due to cement manufacturing companies. As we know that the production of cement from its raw materials produces $\mathrm{CO}_{2}$ and harmful pollutants into the environment. Going into our project work is to lower the production of the cement by partially replacing it with saw dust i.e., wooden powder. The problem with the wood is its high-water absorption capacity, to negotiate this problem the SSD condition is evaluated on the taken saw-dust. The percentage replacement would be as $5 \%, 10 \%$ and $15 \%$ is allowed to go for casting, before passing all its fresh property tests, so after then it is allowed for curing and to analyze its mechanical properties as compression test, tensile, flexural and impact test. Out of all the mechanical tests the above four determines the nature and quality of concrete. As of its past study it is came to know that $5 \%$ replacement of saw-dust give better impact strength due to its fibrous nature of the wooden particle. Finally, in our project we want to produce a better concrete is eco-friendly and to satisfy all the needs of construction industry.
\end{abstract}

\section{INTRODUCTION}

India a major developing country where it fosters its infrastructure to greater level as to satisfy its population and to make them live comfortably. to accommodate the increasing population in India leads in increasing demand for construction which finally resulted in increasing demand for the material ingredients for concrete. but, from the environmental perspective the waste and by-products from industries and as well from agricultural practices has been a severe problem to the society where the huge dumping of these materials resulted in land loss [1] for the living. the materials like coconut shell, rice husk, saw-dust, coir, fly-ash, etc., are creating problem of disposal. Thus in process of research in eliminating this problem, researchers found an alternative for concrete. the partial or full replacement of disposed materials to concrete ingredients, in rapid process of experimentation some materials found an alternative in them coconut shell as a coarse aggregate, fly-ash and marble dust as a cement, ricehusk ash as cement and many more [2]. in the present study of this paper the use of two materials coconut shell and saw-dust, where coconut shell as full replacement to coarse aggregate and saw-dust as partial replacement to fine aggregate [3].

\section{MATERIAL PROPERTIES}

The main source for preparing a concrete specimen or a structure is its ingredient materials, the ingredients are collected from different source points which are nearer to the experimentation laboratory [4]. The mix grade selected is M20 and is designed according to Indian standard code 10262-2009.

Mix Grade=M20. Control concrete $=1: 1.76: 3.35: 0.50$ Coconut shell concrete $=1: 1.12: 0.86: 0.42$

In the above mix proportions sand is partially replaced by volume with sawdust in the percentages of $5 \%, 10 \%$ and $15 \%$.

\subsection{Cement}

OPC 53 grade cement is selected for the preparation of specimens of sizes Cube: $100 \mathrm{~mm} \times 100 \mathrm{~mm} \times 100 \mathrm{~mm}$, Cylinder: $200 \mathrm{~mm} \times 100 \mathrm{~mm}$, Beam: $500 \mathrm{~mm} \times 100 \mathrm{~mm} \times 100$ $\mathrm{mm}$ and Impact disk: $150 \mathrm{~mm} \times 65 \mathrm{~mm}$. the detail properties [5] of cement are shown in following Table 1.

Table 1. Properties of cement

\begin{tabular}{ccc}
\hline S. No & Description & Value \\
\hline 1 & Normal consistency & 31 \\
2 & Initial setting time & $31 \mathrm{~min}$ \\
3 & Specific gravity & 3.05 \\
\hline
\end{tabular}

\subsection{Sand}

Sand is the major composition of Quartz, which makes sand a tough material and non-water absorbent [6]. The sand is collected from the nearby river and sieved through $4.75 \mathrm{~mm}$ sieve. The tested results are as in Table 2. 
Table 2. Properties of sand

\begin{tabular}{ccc}
\hline S. No. & Description & Value \\
\hline 1 & Specific gravity & 2.72 \\
2 & Density & 1680.00 \\
3 & Fineness modulus & 2.730 \\
\hline
\end{tabular}

\subsection{Coarse aggregate}

It is another most important material after sand, which helps in improving the strength of concrete. Its shape, size and crushing strength will affect the concrete severely either in good strength or in worst condition [7]. The size taken is 12.5 $\mathrm{mm}$ and shape are angular. The properties are as in Table 3.

Table 3. Properties of coarse aggregate

\begin{tabular}{lcc}
\hline S. No. & Description & Value \\
\hline 1 & Specific gravity & 2.7 \\
2 & Density & 1623 \\
3 & Maximum size & $12.5 \mathrm{~mm}$ \\
\hline
\end{tabular}

\subsection{Coconut shell}

The coconut shell was collected from the nearby hotels and temples then, cleaned properly and the fiber on the shell is removed and the top surface of shell is made smooth and crushed into pieces by breaking it with a hammer at the laboratory [8]. The maximum size allowed for concrete is 12.5 $\mathrm{mm}$. Before mixing, the shell is soaked in water for $24 \mathrm{hrs}$ and then dried in sunlight for 60 minutes before casting.

This is because to avoid the problem in $\mathrm{W} / \mathrm{C}$ ratio of concrete [9], the dry shell absorbs more water when it consumes its total capacity if water it never receives additional water again. The properties were as followed in the following table 4 .

Table 4. Properties of coconut shell

\begin{tabular}{ccc}
\hline S. No. & Description & Value \\
\hline 1 & Maximum size & $12.5 \mathrm{~m}$ \\
& & $\mathrm{~m}$ \\
2 & Water absorption & $26 \%$ \\
3 & Fineness modulus & 6.5 \\
4 & Specific Gravity & 1.3 \\
5 & Shell thickness & $1.9-8$ \\
& & $\mathrm{~mm}$ \\
6 & Crushing value & $2.78 \%$ \\
\hline
\end{tabular}

\subsection{Sawdust}

Sawdust is another material that challenges the concrete in terms of strength and also in water absorption. Here, the sawdust is collected from the "mastan saw-mill, Autonagar, Guntur". The material available in fine powder is collected and it sieved through $4.75 \mathrm{~mm}$ sieve and then it is allowed to soak in water for $10-12 \mathrm{hrs}$ which, in result does not disturbs the $\mathrm{W} / \mathrm{C}$ ratio of mix. The properties are as follows in Table 5.

Table 5. Properties of sawdust

\begin{tabular}{lcc}
\hline S. No. & Description & Value \\
\hline 1 & Maximum Size used(mm) & $>4.75$ \\
2 & Water Content $(\%)$ & 28.2 \\
3 & Sp. Gravity & 0.35 \\
\hline
\end{tabular}

\section{RESULTS AND DISCUSSION}

The experimental tests performed on the concrete in this paper are Compressive strength, Tensile, flexural and impact, the optimum compression strength at respective mix is considered as the optimum mix and the remaining tests are done only to the optimum mixes [10]. This is because as everyone knows that concrete is strong in compression; once the specimen strengthens in compression it would pass all the other tests at reasonable standard.

\subsection{Compression test}

Table 6. Compressive strength different concrete mixes

\begin{tabular}{|c|c|c|c|c|}
\hline \multicolumn{5}{|c|}{ Compressive strength(N/mm $)$} \\
\hline Mix & $\begin{array}{c}\text { Partial } \\
\text { Replacement } \\
\text { of sawdust }\end{array}$ & Day 7 & Day 14 & Day 28 \\
\hline Control & $0 \%$ & 8.26 & 13.12 & 24.65 \\
\hline concrete with & $5 \%$ & 9.30 & 12.52 & 22.12 \\
\hline partial & $10 \%$ & 6.80 & 9.37 & 17.20 \\
\hline $\begin{array}{l}\text { replacement } \\
\text { of sawdust } \\
\text { ( } \mathrm{Sd} C \mathrm{C})\end{array}$ & $15 \%$ & 3.20 & 6.70 & 10.92 \\
\hline Coconut & $0 \%$ & 9.21 & 11.50 & 21.96 \\
\hline shell & $5 \%$ & 10.67 & 15.23 & 21.27 \\
\hline concrete with & $10 \%$ & 6.72 & 9.52 & 15.12 \\
\hline $\begin{array}{c}\text { partial } \\
\text { replacement } \\
\text { of sawdust } \\
\text { (Sd CSC) }\end{array}$ & $15 \%$ & 2.41 & 5.31 & 6.40 \\
\hline
\end{tabular}

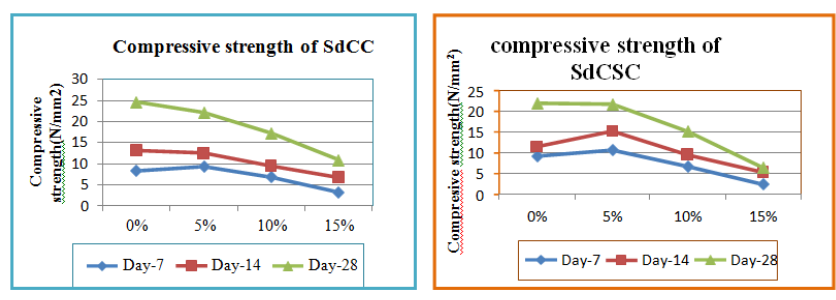

Figure 1. Graphical representation compression test values of the different mixes

Compressive strength is the internal resistivity of the material occurred from in specimens. Simply, resistance of a body towards the compressive loads applied on a specimen [11]. Here in, the specimens used are of size $100 \mathrm{~mm} \times 100$ $\mathrm{mm} \times 100 \mathrm{~mm}$. test days are 7days, 14days and 28days with volume replacement of sawdust with $5 \%, 10 \%$ and $15 \%$ in both control concrete and lightweight concrete. The test results are as followed in table 6 .

The above graphical representations in the above Figure 1 clearly show that the compressive strength of concrete at $5 \%$ replacement of sawdust in both control and coconut shell concrete has given the better result than the other percentage mixes [12]. Now, here in the $5 \%$ replacement is taken as the optimum mix proportion and the same mix carried to the other tests and compared to control concrete.

\subsection{Split-tensile test}

It is the resistance towards the force that is applied away from the body that tries the specimen to split in two pieces. Here in on this study the specimens tested are of size $200 \mathrm{~mm} \times 100 \mathrm{~mm}$ and are allowed to test in compressive testing 
machine by placing the specimen horizontally with just a line of contact on to the jaw surface [13]. The test results of the specimens are as followed in the Table 7.

Table 7. Split tensile test values

\begin{tabular}{|c|c|c|c|c|}
\hline \multicolumn{5}{|c|}{ Tensile strength(N/mm $\left.{ }^{2}\right)$} \\
\hline Mix & Sawdust & Day-7 & Day-14 & Day-28 \\
\hline $\mathrm{CC}$ & $0 \%$ & 2.34 & 3.75 & 4.12 \\
\hline $\mathrm{Sd}$ CC & $5 \%$ & 2.21 & 4.01 & 4.25 \\
\hline $\mathrm{CSC}$ & $0 \%$ & 1.09 & 2.02 & 2.8 \\
\hline $\mathrm{Sd}$ CSC & $5 \%$ & 1.53 & 2.97 & 3.26 \\
\hline
\end{tabular}

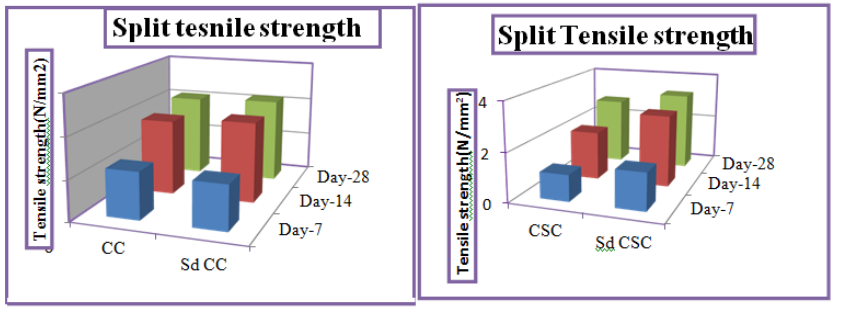

Figure 2. Graphical representation of flexural test values at $5 \%$ replacement of sawdust

The above test results show that the tensile strength at $5 \%$ replacement of sawdust in both control concrete and Coconut shell concrete gives the best results when compared to normal concrete [14]. This is due to the reason that both sawdust and coconut shell are the wooden materials which has great resistance towards the tensile loading. Hence, the specimens have followed the passed the 2 nd test.

\subsection{Flexure test}

Another most important property of the concrete which has to keep in mind is flexural strength [15]. It is the property of bending, this test is performed on a beam specimen of size $500 \mathrm{~mm} \times 100 \mathrm{~mm} \times 100 \mathrm{~mm}$ and allowed test to in Compression testing machine with three pointer loading frame. The test results are as follows in Table 8 .

Table 8. Flexure test values

\begin{tabular}{lllll}
\hline \multicolumn{5}{c}{ Flexure strength $\left.\mathbf{( N} / \mathbf{m m}^{\mathbf{2}}\right)$} \\
\hline Mix & Sawdust & Day-7 & Day-14 & Day-28 \\
CC & $0 \%$ & 2.16 & .3 .35 & 4.27 \\
Sd CC & $5 \%$ & 2.21 & 3.27 & 4.25 \\
& & & & \\
CSC & $0 \%$ & 2.01 & 2.59 & 3.94 \\
Sd CSC & $5 \%$ & 2.04 & 2.78 & 4.01 \\
\hline
\end{tabular}

The above results of the bending resistance test values are much greater when compared to the respective control concrete specimens [16]. Thus slight change of strength doesn't affect the concrete, thus the tested materials are considerable for the manufacturing of concrete.

\subsection{Impact test}

The property of sudden application of load on the body is called Impact load [17]. These types of loads are mostly considered in transportation constructions; wood is the natural material which resists to more impact loads. Keeping this in view the concrete is allowed to test for impact loads with these material ingredients. The test values are in following Table 9.

Table 9. Impact test values

\begin{tabular}{|c|c|c|c|}
\hline \multicolumn{4}{|c|}{ Impact test } \\
\hline Mix & Saw-dust & No. of blo & for 28davs \\
\hline $\mathrm{Sd} C \mathrm{C}$ & $5 \%$ & $\begin{array}{c}\text { Initial crack } \\
189\end{array}$ & $\begin{array}{c}\text { Final break } \\
246\end{array}$ \\
\hline Sd CSC & $5 \%$ & 116 & 139 \\
\hline
\end{tabular}

The above test results clearly prove that addition of wood in concrete may increase its impact resistance, but in the case of coconut shell concrete it has shown low resistance. this is due the adding of more wooden material to the concrete may result in low resistance.

\section{CONCLUSION}

From the above all the experiments and the practical information it was to conclude that:

(1) The concrete with these materials can be preferred only with some limitations like, usage in hot conditions where there is a less amount of moisture in the climate.

(2) The presence of sawdust in concrete frightened the researchers by its heavy water absorption capacity. But, soaking it in water for 10-12 hours may eliminate the problem.

(3) Finally, it is to conclude that the replacements of sawdust and coconut shell in concrete has shown greater impact in developing the eco-friendly construction.

Future stage of work would be addition of coir fiber to the same optimum mix of $5 \%$ replacement if sawdust in both CC and CSC.

\section{REFERENCES}

[1] Adebakin, I.H. (2012). Uses of saw dust as admixture in production of low cost and light weight. 2012 American Journal of Scientific and Industrial Research, 3(6): 458463.

[2] Gunasekaran, K., Kumar, P.S. (2008). Lightweight concrete using coconut shells as aggregate. Conference: International Conference on Advances in Concrete and Construction, ICACC-2008, At Hyderabad, India.

[3] Abdullahi, A., Abubakar, M., Afolayan, A. (2013). Partial replacement of sand with saw dust in concrete production. 3rd Biennial Engineering Conference, Federal University of Technology, Minna. https://doi.org/ 10.13140/2.1.2742.0804

[4] Cheng, Y., You, W., Zhang, C.Y., Li, H.H., Hu, J. (2013). The implementation of waste saw dust in concrete. Science Research, 5: 943-947. http://dx.doi.org/10.4236/eng.2013.512115

[5] Reddy, B.D., Jyothy, S.A., Shaik, F. (2014). Experimental analysis of the use of coconut shell as coarse aggregate. IOSR Journal of Mechanical and Civil Engineering, 10(6): 6-13.

[6] Kumar, D., Singh, S., Kumar, N., Gupta, A. (2014). Low cost construction material for concrete as sawdust. Global Journal of Researches in Engineering, 14(4).

[7] Dehwah, H.A.F. (2012). Mechanical properties of selfcompacting concrete incorporating quarry dust powder, 
silica fume or fly ash. Construction and Building Materials, 26(1): 547-551. https://doi.org/10.1016/j.conbuildmat.2011.06.056

[8] Boob, T.N. (2014). Performance of saw-dust in low cost sandcrete block. American Journal of Engineering Research, 3(4): 197-206.

[9] Elinwa, A.U., Ejeh, S.P., Mamuda, A.M. (2008) Assessing of the fresh concrete properties of selfcompacting concrete containing sawdust ash. Construction and Building Materials, 22(6): 1178-1182. https://doi.org/10.1016/j.conbuildmat.2007.02.004

[10] Elinwa, A.U., Ejeh, S.P., Akpabio, I.O. (2005). Using metakaolin to improve sawdust-ash concrete. Concrete International, 27(11): 49-52.

[11] Ho, D.W.S., Sheinn A.M.M., Ng, C.C., Tam, C.T. (2002). The use of quarry dust for SCC applications. Cement and Concrete Research, 32(4): 505-511. https://doi.org/10.1016/S0008-8846(01)00726-8

[12] Ilangovana, R., Mahendrana, N., Nagamanib, K. (2008). Strength and durability properties of concrete containing quarry rock dust as fine aggregate. ARPN Journal of Engineering and Applied Sciences, 3(5): 20-26.

[13] Lohani, T.K., Pahi, M., Dash, K.P., Jena, S. (2012). Optimum utilization of quarry dust as partial replacement of sand in concrete. International Journal of Applied Science and Engineering Research.

[14] Oyedepo, O.J., Oluwajana, S.D., Akande, S.P. (2014). Investigation of Properties of Concrete Using Sawdust as Partial Replacement for Sand. Department of Civil Engineering, Federal University of Technology, Akure, Nigeria.

[15] Paramasivam, P., Loke, Y.O. (1980). Study of sawdust concrete. International Journal of Cement Composites and Lightweight Concrete, 2.1(1980): 57-61. https://doi.org/10.1016/0262-5075(80)90008-1

[16] Raman, S.N., Ngo, T., Mendis, P., Mahmud, H.B. (2011). High-strength rice husk ash concrete incorporating quarry dust as a partial substitute for sand. Construction and Building Materials, 25(7): 3123-3130. https://doi.org/10.1016/j.conbuildmat.2010.12.026

[17] Sales, A., Rodrigues de Souza, F., Nunes dos Santos W., MendesZimer, A., Couto Rosa Almeida, F.D. (2010). Lightweight composite concrete produced with water treatment sludge and sawdust: thermal properties and potential application. Construction and Building Materials, 24(12): 2446-2453. https://doi.org/10.1016/j.conbuildmat.2010.06.012 